\title{
分婏前後における乳用牛群に対する 免疫プロファイルテストの有用性
}

\author{
渡辺知香 ${ }^{1)} \quad$ 大塚浩通 $^{1{ }^{\dagger}} \quad$ 小比類巻正幸 ${ }^{1), 2)} \quad$ 铇田真弓 $^{1)} \quad$ 寺澤早紀子 ${ }^{1)}$ \\ 安藤貴朗 ${ }^{1)} \quad$ 渡辺大作 ${ }^{1)}$ 佐藤 繁 $^{3)}$

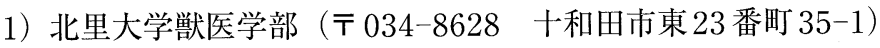 \\ 2）青森県 開業（广 039-2683 上北郡東北町大平 63-3） \\ 3）宮城県農業共済組合連合会（† 989-0731 白石市福岡深谷字桜丘前 10） \\ (2006 年 10 月 10 日受付・ 2007 年 2 月 22 日受理)
}

要 約

牛群における免疫プロファイルテストの有用性を明らかにするため, 飼養管理が異なる $\mathrm{A}, \mathrm{B}$ おび $\mathrm{C}$ 群において代 謝プロファイルテストに加え, 未梢血単核球の解析を試みた. A および $\mathrm{B}$ 群の周産期疾病の発生率が $\mathrm{C}$ 群に比べ高かっ た．血液生化学成績において A 群では乾乳期に遊離脂肪酸（NEFA）が他の 2 群に比べ高值であり，B群では乾乳期か ら泌乳期にかけて総コレステロール（TC）と血糖值が他の 2 群に比べ高值であった。C群ではこれらの成績はほぼ正常 範囲内にあった。免疫学的検査から A 群では, 分娩後 1 から 4 力月にかけて CD $4^{+} / \mathrm{CD} 8^{+}$比および IFN $-\gamma / \mathrm{IL}-4$ 比が B 群と C 群に比べ低い傾向にあった。これらのことから牛群における免疫プロファイルテストは牛群の免疫状態を評価す るために有用であり, 乾乳期の飼料設計に不足のあった A 群では分婏後に細胞性免疫機能が低下しているものと示唆さ れた。一ーキーワード：乾乳期, 免疫プロファイル, 栄養, 周産期疾病.

日獣会誌 $60,709 \sim 714 （ 2007 ）$

近年，酪農は経営規模の拡大および高泌乳化に伴って 生産性が向上したが, 乳牛の産次数は低下し, 死廃・病 傷事故も減少する兆しは見られない. そのため経営の上 で牛群での疾病の発生状況を把握し, 牛群の問題点を修 正するような管理が必要である．牛群管理の中でも分婏 後の疾病発生は乾乳期の飼養管理と密接に関わっている [1-3]ことから, 乾乳期の栄養状態を的確に把握するこ とは分娩前後の周産期疾病の発症を予防する手がかりに なると考えられる。こうしたことから疾病を予防し生産 性を向上させるために，牛群の問題点を明らかにする代 謝プロファイルテストが国内でも普及している.

周産期疾病の発症要因として分娩前後の栄養代謝, 内 分泌機能や免疫機能の急変などがあげられる $[4,5]$. こ のうち免疫状態に関しては, 周産期の乳牛において分娩 時に好中球やリンパ球機能が生理的に低下する [6]こ とから, 分娩後に感染症を発症しやすいと考えられてい る。また，これまで乳房炎の多発する牛群や周産期疾病 が多い牛群に対して, 代謝プロファイルに免疫学的検査
を加えた免疫プロファイルテストが実施されている $[7-$ 9]. それによれば乳房炎の多発する牛群では, 牛群全体 に蛋白質不足と $\mathrm{T}$ 細胞数の低下のあることや，周産期疾 病が多発した牛群では血清サイトカイン活性の高值を認 めることが報告されている，すなわち，牛群に対する免 疫プロファイルテストの実施は対象牛群の免疫状態を評 価するために有用であると考えられる．しかし，周産期 疾病の発生状況や牛群の栄養状態と免疫状態の関係に関 する詳細はいまだ不明な点が多い.

そこで本研究では栄養状態と免疫機能との関連性を明

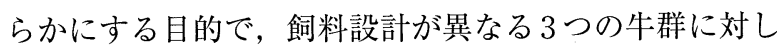
て血液代謝プロファイルテストに加えて免疫学的検査, すなわち免疫プロファイルテストを実施した。

\section{材料および方法}

供試牛：3戸の乳用牛群より無作為に選別した牛をお のおの $\mathrm{A} ， \mathrm{~B}$ おび $\mathrm{C}$ 群とし，それらの牛群において分 婏前 60 日 31 日（-2 から-1 力月）, 分婏前 30 日か

$\dagger$ 連絡責任者: 大塚浩通（北里大学獣医学部大動物内科学研究室） ₹ 034-8628 十和田市東 23 番町 $35-1$

20176-23-4371 FAX 0176-23-8703

E-mail : otsuka@vmas.kitasato-u.ac.jp 
表 1 各群の周産期疾病の発生率

\begin{tabular}{lrrr}
\hline \hline \multicolumn{1}{c}{ 疾 病 } & A群 & B群 & C群 \\
\hline ケトーシス $(\%)$ & 10.3 & 3.0 & 3.8 \\
乳 熱 $(\%)$ & 15.4 & 9.1 & 1.3 \\
第四胃変位 $(\%)$ & 10.3 & 9.1 & 2.6 \\
胎盤停滞 $(\%)$ & 9.0 & 15.2 & 1.3 \\
\hline
\end{tabular}

成績は周産期に治療した頭数の割合. 平均治療回数はA 群3.4回, B群2.8回, C群3.2回

ら1日（-1から0カ月), 分浼 0 日から. 30 日（0から 1 力月), 分婏後 31 日～60日 (1 加 2 力月), 分娩後 61 日～90日（2から 3 力月），分婏後 91 日～120日（3か ら 4 カ月）にある個体を対象に各期間，既往歴のない乳 牛 6 頭を選別し，各時期に 1 回採血した。各牛群の一頭 当たり平均年間泌乳量は $\mathrm{A}$ 群で $8,300, \mathrm{~B}$ 群で $8,550, \mathrm{C}$ 群で $8,300 \mathrm{~kg}$ であった. 分婏前の周産期疾病の発生率は A 群で最も高く, 次いでB群が高かった. C 群における 周産期疾病の発生率は他の 2 群に比べ低かった（表 1 ). 採血は午後 1 時から 3 時までに実施した。また飼料設計 の分析結果として，乾物摂取量充足率 (DMI；\%)，粗 蛋白質充足率 (CP; \%), 可消化養分総量充足率 ( T D N ; \% )，中性デタージェント繊維含有量 (NDF; \%), 酸性デタージェント繊維含有量 (ADF; \%), 非繊維性炭水化物含有量（NFC；\%）を表 2 に示した。

血液の採材と処理法：供試牛の尾静脈から採血し，血 清分離剂入りの真空採血管, EDTA- $2 \mathrm{Na}$ 添加真空採血 管，ヘパリン添加真空採血管 $10 \mathrm{~m} l$ およびフッ化 $\mathrm{Na}$ 添 加真空採血管に分注した.

血液検查：白血球数（WBC）は自動血球計算装置 （PC607，ERMA，Germany）により測定した。血液生 化学検査として, 血清 $\beta$ ヒドロキシ酪酸（BHB；酵素 法), 総コレステロール (TC; 酵素法), 血中尿素窒素 (BUN; Urease indophenol法), 血清非エステル型脂 肪酸 (NEFA; 酵素法), 血糖（酵素法）の測定を行っ た。

白血球サブポピュレーションの解析：白血球表面抗原 の解析は, 定法に従い実施し [10], CD3（MMIA， VMRD, Pullman, WA, U.S.A.), CD4 (CACT183A, VMRD), CD8 (BAT82A, VMRD), MHC class II (CAT82A, VMRD) および CD14（MY-4, Coulter Immunology, Hialeah, Florida, U.S.A.) に対する抗体 を用いた. なお，各細胞の数值はフローサイトメーター (FACScan, Becton Diskinson, U.S.A.) により解析し た比率と WBC 值から算出した実数值によって数を求め た。

サイトカイン遺伝子の発現量の解析 : 末梢血単核球の 培養は血液から分離し， $5 \times 10^{6}$ 個 $/ \mathrm{m} l$ となるように調 整した。これまでの方法と同様に [11]，細胞には $5 \mu \mathrm{g} /$
表 2 各群の飼料設計

\begin{tabular}{|c|c|c|c|c|}
\hline 泌乳期 & & A群 & B群 & C群 \\
\hline \multirow{6}{*}{$\begin{array}{l}-2 \text { から } \\
-1 \text { 力月 }\end{array}$} & DMI $(\%)$ & 100.0 & 91.2 & 94.6 \\
\hline & $\mathrm{CP} \quad(\%)$ & 90.6 & 94.6 & 84.6 \\
\hline & $\mathrm{TDN}(\%)$ & 113.1 & 112.6 & 114.2 \\
\hline & $\mathrm{NDF}(\%)$ & 63.8 & 51.4 & 61.6 \\
\hline & $\mathrm{ADF}(\%)$ & 37.5 & 27.7 & 35.7 \\
\hline & $\mathrm{NFC}(\%)$ & 13.6 & 27.3 & 20.9 \\
\hline \multirow{6}{*}{$\begin{array}{c}-1 \text { から } \\
0 \text { カ月 }\end{array}$} & DMI $(\%)$ & 106.5 & 104.9 & 100.0 \\
\hline & $\mathrm{CP} \quad(\%)$ & 100.6 & 107.5 & 99.3 \\
\hline & $\mathrm{TDN}(\%)$ & 108.3 & 113.4 & 105.7 \\
\hline & NDF $(\%)$ & 54.7 & 44.6 & 45.2 \\
\hline & $\mathrm{ADF}(\%)$ & 31.8 & 24.2 & 26.3 \\
\hline & $\mathrm{NFC}(\%)$ & 21.3 & 32.3 & 32.3 \\
\hline \multirow{6}{*}{$\begin{array}{l}2 \text { から } \\
4 \text { カ月 }\end{array}$} & DMI $(\%)$ & 110.5 & 108.0 & 109.4 \\
\hline & $\mathrm{CP} \quad(\%)$ & 97.3 & 90.2 & 90.1 \\
\hline & $\mathrm{TDN}(\%)$ & 100.2 & 100.3 & 98.9 \\
\hline & NDF (\%) & 36.0 & 37.5 & 38.8 \\
\hline & $\mathrm{ADF}(\%)$ & 19.2 & 20.8 & 23.5 \\
\hline & $\mathrm{NFC}(\%)$ & 35.3 & 36.5 & 36.3 \\
\hline
\end{tabular}

$\mathrm{NRC}$ 飼養標準により算出

充足率は平均体重 $650 \mathrm{~kg}$ で算出

泌乳最盛期の設計は平均乳量 $40 \mathrm{~kg} /$ 日, 脂肪率 $3.7 \%$ で計算

DMI， CP，DIP，SIP，NEI，TDNは充足率，NDF，

$\mathrm{ADF}, \mathrm{NFC}$ 含有率で表示

分婏を0として表示

$\mathrm{m} l$ の フトヘマグルチン (PHA-P; Sigma-Aldrich CO, St.Louis, U.S.A.）を加え，12時間培養した．培養 した細胞から RNA を抽出し, サンプルのRNA濃度を測 定した。抽出したRNAから定法により [10]，cDNAの 合成（逆転写反応）およびリアルタイム PCR を実施し た。 また腫瘍壊死因子 $(\mathrm{TNF})-\alpha$, インターフェロン (IFN) - $\gamma$, インターロイキン (IL) -4 の各種サイトカイ ンおよび $\beta$-Actinの PCR プライマーデザインはRiollet ら［10］の報告を参考にし, 各サイトカイン産生能は $\beta-$ Actin を内部標準として, 無刺激の培養細胞でのサイト カインの mRNA 発現量を 1 とした場合の PHA 刺激培養 細胞におけるサイトカインの mRNA 発現量を比較する 比較定量法（ $\Delta \Delta \mathrm{Ct}$ 法）によって算出した。

検定：検查成績は一元配置分布後にScheffe の方法に より 2 群間の比較を行い解析した. 分散分布が正しくな いものについてはKruskal Wallis Testを行い, Scheffe の方法により 2 群間の比較を行い解析した。いずれも $5 \%$ 以下の危険率で有意な差とした.

\section{成績}

飼料設計の成績から，すべての群の -2 から -1 カ月 と分娩後の DMI とTDNの設計は充足されており, 各群 間に差はなかった。しかし A 群ではC 群に比べ分婏前 1 カ月の NDF と ADF含有率が高く $\mathrm{NFC}$ 含有率が低かっ た.いっぽう, B 群では $\mathrm{C}$ 群に比べー 2 から-1 カ月に 

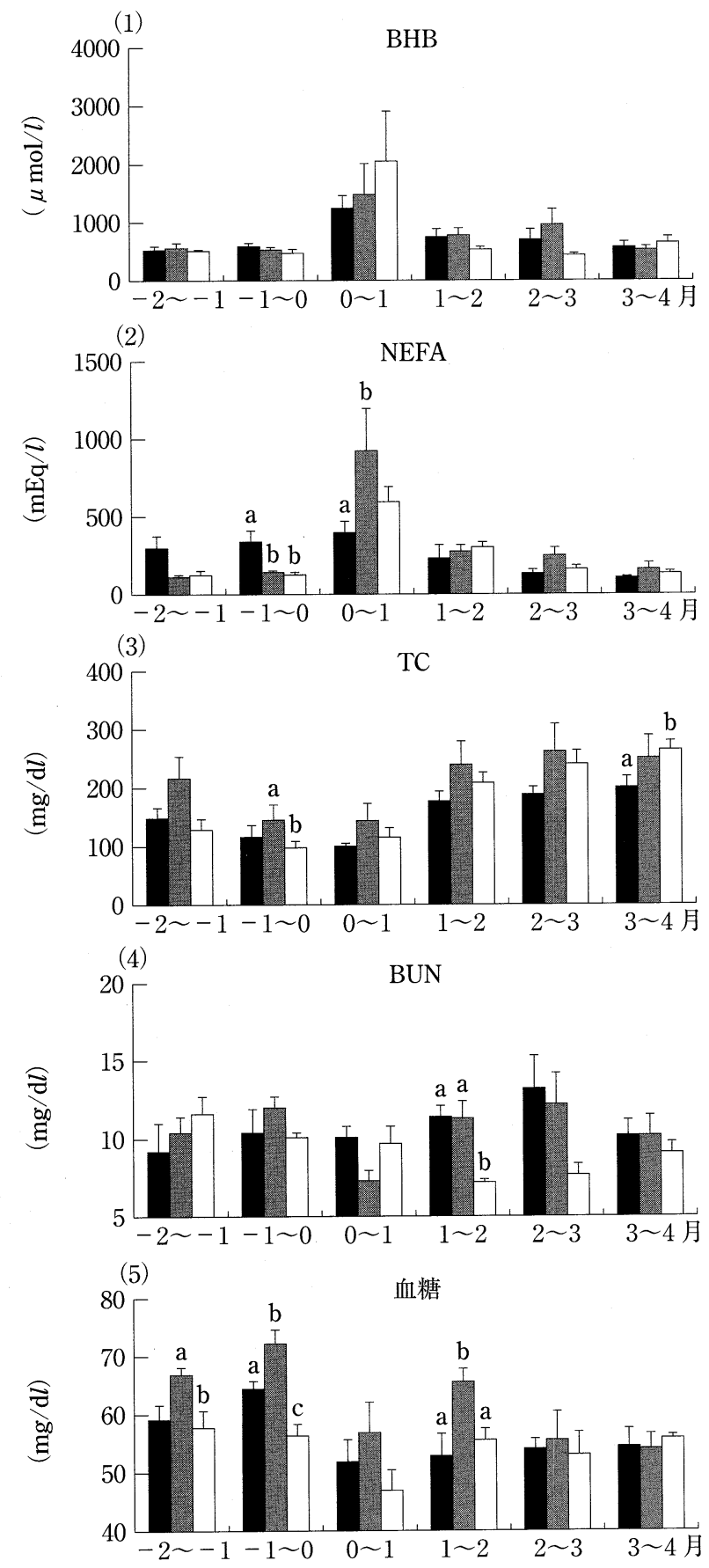

図 1 各群の血液生化学検查所見の比較

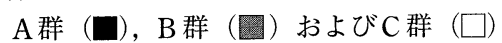
$\mathrm{abc}$ 異符号間に有意差あり $(P<0.05)$. 0 は分娩，マイナスは分婏前を示す.

おける $\mathrm{NDF}$ 含有量および $\mathrm{ADF}$ 含有量が低く, $\mathrm{NFC}$ 含 有量が高かった。さらにー 1 から 0 カ月におけるB群の $\mathrm{CP}$ およびTDN 充足率は C 群に比べ高かった。分娩後 の飼料設計值は 3 群間に明瞭な差を認めなかった（表 2). 3 群における 0 から 2 力月の設計值は標準值を充足 しており，3群間での差も認められなかった（成績示さ ず).

血清 $\mathrm{BHB}$ 值は，1 から 3 カ月において $\mathrm{A}$ および $\mathrm{B}$ 群
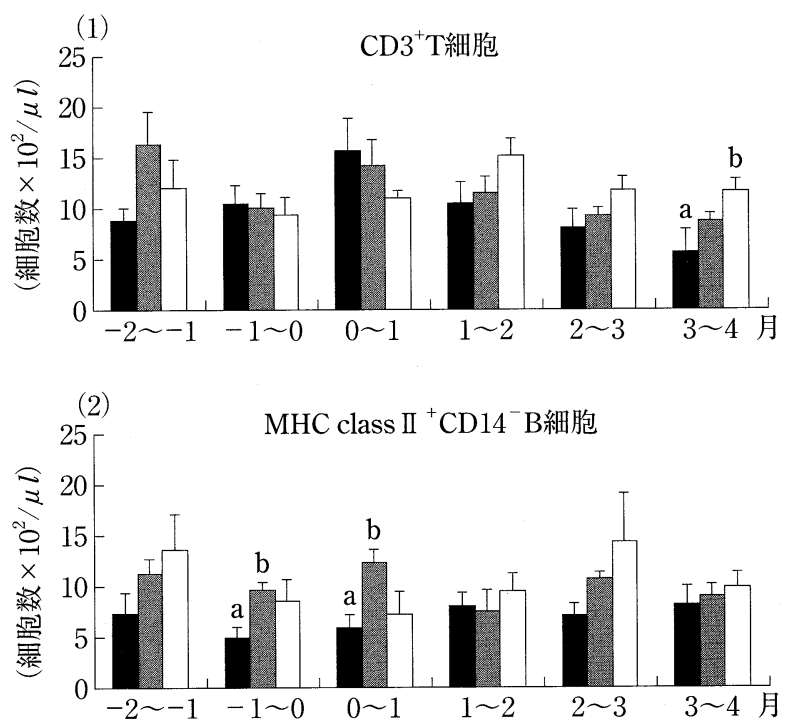

図2 各群の $\mathrm{CD} 3{ }^{+} \mathrm{T}$ 細胞と $\mathrm{MHC}$ class $-\Pi^{+} \mathrm{CD} 14^{-} \mathrm{B}$ 細胞 数の比較

$\mathrm{A}$ 群 (口)，B群（圆）およびC 群（ $\square ）$

$\mathrm{ab}$ 異符号間に有意差あり $(P<0.05)$.

0 は分婏，マイナスは分婏前を示す.
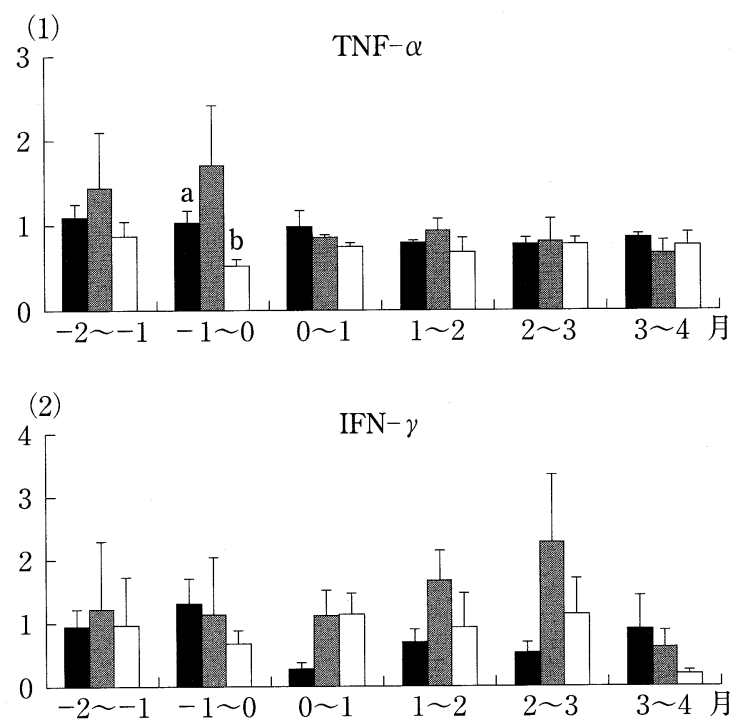

図3 各群の TNF- $\alpha$ と IFN $-\gamma$ 遺伝子発現量の比較

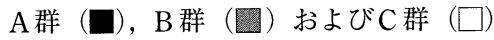
$\mathrm{ab}$ 異符号間に有意差あり $(P<0.05)$. 0 は分娩，マイナスは分娩前を示す.

でC 群に比べ高值を示す傾向を示したが，観察した各期 間において有意な差は認められなかった。血清 NEFA 值は, -1 から-0 月月において $\mathrm{A}$ 群が他の 2 群に比べ 有意に高かったが，0〜1 カ月においては B 群が $\mathrm{A}$ 群に 比べ有意な高值を示した。 $\mathrm{TC}$ 值は， -2 力月から 3 力 月において $\mathrm{B}$ 群が他の 2 群に比べ高值を示す傾向にあ り， - 1 から 0 カ月では $\mathrm{C}$ 群と比較し有意差を認めた. また $\mathrm{A}$ 群は分娩後の各期間に他の 2 群に比べ低い傾向に あり，3 から 4 力月において C 群に比べ有意に低い值を 

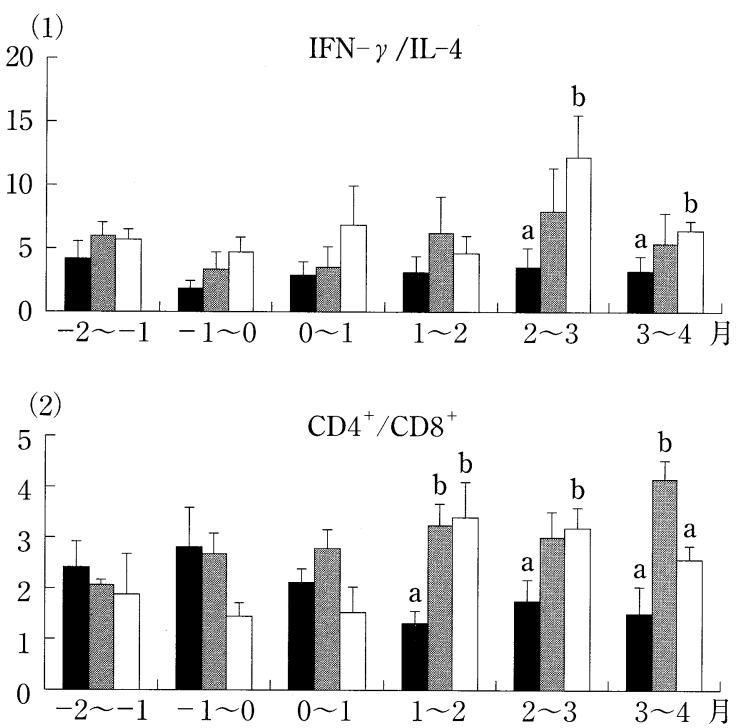

図4 各群の $\mathrm{IFN}-\gamma / \mathrm{IL}^{-} 4$ 比と $\mathrm{CD} 4^{+} / \mathrm{CD}^{+}$比の比較 $\mathrm{A}$ 群 (口)，B群（回）およびC 群 ( $\square$ ) $\mathrm{ab}$ 異符号間に有意差あり $(P<0.05)$. 0 は分婏，マイナスは分婏前を示す。

認めた. C 群のBUNは, 1 から 4 カ月において他の 2 群 に比べ低い傾向にあり，1 から 2 力月において他の 2 群 と比較して有意差を認めた． B 群の血糖值はー 2 から 3 カ月において他の 2 群と比較して高い傾向にあり, -2 からー1 カ月においてCとの間に, またー 1 からー0カ 月ならびに 1 から 2 カ月においては他の 2 群と比較して 有意な差を認めた（図 1 ).

$\mathrm{A}$ および $\mathrm{B}$ 群の $\mathrm{CD} 3^{+} \mathrm{T}$ 細胞数は $\mathrm{C}$ 群に比べ 1 から 4 カ月にかけて低い傾向にあり，3から4 カ月において $\mathrm{A}$ 群ではC 群に比べ有意に低い值を示した。 $\mathrm{A}$ および $\mathrm{B}$ 群 の $\mathrm{CD} 4^{+} \mathrm{T}$ 細胞数は $\mathrm{C}$ 群に比べ 1 から 4 力月にかけて低 い傾向にあったものの, $\mathrm{CD}^{+} \mathrm{T}$ 細胞数には特出した差 を認めなかった（成績表記せず）. A 群の MHC class II ${ }^{+} \mathrm{CD} 14^{-}$数は 1 から 2 力月を除き他の 2 群に比べ低い 傾向にあり，-1から 1 カ月においてB 群と比較して有 意な低值を認めた（図2）. 分娩前の $\mathrm{A}$ 群および $\mathrm{B}$ 群の $\mathrm{TNF}-\alpha$ 值は C 群に比べ高い傾向にあり, A 群の TNF$\alpha$ 值は C 群と比較し -1 から 0 カ月において有意な高值 を認めた. A 群の IFN- $-\gamma$ 值は 0 から 3 カ月において他の 2 群に比べ低い值を示した。また 1 から 3 カ月において はB 群の IFN- $\gamma$ 值が他の 2 群に比べ高かった（図3）. いっぽう, IFN- $\gamma / \mathrm{IL}-4$ 比では各期間を通して A 群が 他の 2 群に比べ低い傾向にあり，2 から 4 力月において $\mathrm{C}$ 群と比較して有意な低值を認めた。 さらにCD4/CD8 比では, 1 から 4 カ月にかけて A 群が他の 2 群に比べ低 い傾向にあり，1から 2 力月ならびに 3 から 4 力月にはB ならびにC 群と, また 2 から 3 力月においてはC 群との 間に有意な差を認めた（図4).

\section{考} 察

飼料設計の分析結果から, 3 群の飼料設計の特徵とし て分娩後の設計は充足されていたものの，分娩前に違い のあることが示された。すなわち A 群では分婏前におい てTDNは充足されていたものの, 他の 2 群およびNRC で定める基準值に比べて NFC が低く，NDF が高い傾向 にあった．また代謝プロファイルの結果から，分婏前に おいて高NEFAが認められたＡ群において他の 2 群に 比べ周産期疾病の発生率が高い傾向にあった原因とし て，分婏前の NFC 不足によって低調な第一胃発酵とな り，分娩後に泌乳に必要な規定の設計量の飼料を採食で きなかった個体が存在し，分娩後に低血糖や低TCが認 められたものと示唆された.いっぽう, B 群はA群に続 き周産期疾病の発症が多く, 飼料設計の分析結果で は，-2から-1 カ月の NFC と CP が高い傾向にあっ た. 血液代謝プロファイルの結果では， -2 から 3 力月 において本研究の 2 群や，これまで報告 [12] にある健 康乳牛の数值に比べても TC 值と血糖值が高值であっ た.これは分婏前の給与飼料内容が他の牛群に比べ高力 ロリーであることが原因であったと示唆された。乾乳期 から分娩後にかけてのC 群の血液検查所見は, これまで 報告のある健康なものと同等であり [12]，また飼料の 設計值も NRC で定める基準值を満たしていたことから， C群はおおむね健康に管理されていたものと示唆された。

白血球サブポピュレーションの結果から, 周産期疾病 の発生の多かった $\mathrm{A}$ 群は 3 から 4 カ月において総 $\mathrm{T}$ 細胞 である $\mathrm{CD} 3^{+}$細胞が $\mathrm{C}$ 群に比べ低かった. $\mathrm{T}$ 細胞は免疫 応答において種々のサイトカインを分泌し, 他の白血球 機能を調節する役割を持っており, 末梢血液中の T細胞 数が減少するとその機能も低下する $[11,13]$. いっぽ う, 分娩前に低コレステロールにある乳牛では分娩後に $\mathrm{T}$ 細胞が低下傾向で推移することが報告されており [14], 乳牛の分娩前の栄養状態と分娩後の免疫状態には 関連のあることが考えられている．本研究のA群のよう な分娩前後の栄養状態に何らかの問題があり, 疾病が頻 発するような乳用牛群では, 分娩後のT細胞機能にも異 常のある可能性がある. しかし高コレステロールの状態 で管理されていた B 群においても分娩後にT細胞数が減 少する傾向にあり, 乳牛の白血球サブポピュレーション に影響する要因は多く存在するものと考えられ，この要 因を明らかにするために今後の研究が必要である.

ヘルパーT (Th) 細胞はサイトカイン産生パターンに より，Th1とTh2に分類され [15], Th1は IL-2, IFN- $\gamma$ などを分泌し細胞性免疫を誘導, いっぽう Th2 は IL-4，IL-5，IL-6，IL-10などを分泌し液性免疫を 誘導することが知られている [16-18]. 人では持続運 動などの身体的ストレスの他, 試験による心理的ストレ 
スなどさまざまなストレス状態で液性免疫が優位とな り, IL-4 産生が増強され, 易感染性になることが報告 されている $[19,20]$. 乳牛における末梢血リンパ球の IFN- $\gamma$ 遺伝子発現量は IL-4 遺伝子発現量の 10 倍以上 あるが $[21] ， \mathrm{~A}$ 群では過去の報告や B , C 群に比べて 1 から 4 力月にかけて IFN- $\gamma / \mathrm{IL}-4$ 比が低值であった。 またヒトでは $\mathrm{CD} 4^{+} / \mathrm{CD} 8^{+}$比の低下は免疫機能の低下と して考えているが $[22], \mathrm{B}$ および $\mathrm{C}$ 群の $\mathrm{CD} 4^{+} / \mathrm{CD} 8^{+}$ 比は，これまでの泌乳期における健康な乳牛で報告され ている数值と同様であったのに対して $[23,24]$, A 群の 分婏後の各期間の $\mathrm{CD} 4^{+} / \mathrm{CD} 8^{+}$比が低值であった. 乳牛 は乾乳期に低 NFC の飼料管理にあると, 分婏後の $\mathrm{CD} 4^{+} / \mathrm{CD} 8{ }^{+}$比およびIFN- $\gamma / \mathrm{IL}-4$ 比が低下すること が報告されている [11].これらのことから A 群では分 娩後において細胞性免疫機能の低下状態にあったものと 示唆される。

分娩前におけるA群のB細胞である $\mathrm{MHC}$ class II ${ }^{+}$ $\mathrm{CD} 14^{-}$細胞数が B 群に比べ低かった. 分婏前の健康な 乳牛では末梢血 B 細胞数が高く維持しているが，何らか の疾病を発症していない乳牛であっても, 分婏後の血清 総コレステロール值が持続的に低い乳牛では B 細胞数が 低值で推移することも指摘されている [13] ため, 分婏 後の血清総コレステロール值が高かった B 群に比べて, 低かったA群で低 MHC class II ${ }^{+} \mathrm{CD} 14^{-}$細胞数であっ たのは，これまでの報告と類似の成績であったものと示 唆される.

$\mathrm{A}$ 群では- 1 から 0 力月における TNF- $\alpha$ 遺伝子発現 量が $\mathrm{C}$ 群に比べ高かった. 周産期疾病の多発する牛群で は乾乳期における血清TNF 活性が高いと報告されてい るが $[9]$ ，これは今回の単核球のTNF- $\alpha$ 遺伝子発現量 と類似の成績であった。 しかしこの TNF- $\alpha$ 遺伝子発現 量の高值の原因は明確ではなく, 今後の研究が必要であ る.

本研究では，牛群の栄養状態が免疫状態と関連する可 能性を示した。良好な栄養状態によって正常な免疫機能 を維持するためには, 過不足のない適切な飼料給与によ って健康な第一胃発酵を維持させ, エネルギー代謝を促 進することが重要であると考えられる. 末梢血白血球機 能を解析する免疫プロファイルテストは, 牛群の免疫状 態を評価するための一助になるものと示唆された.

\section{引用文 献}

[1] Ostergaard S, Sorensen JT : A review of the feedinghealth-production complex in a dairy herd, Prev Vet Med, 36, 109-129 (1998)

[2 ] Rukkwamsuk T, Kruip TA, Wensing T : Relationship between overfeeding and overconditioning in the dry period and the problems of high producing dairy cows during the postparturient period, Vet Q, 21, 71-
77 (1999)

[3] Van der Meide PH, Schellekens H : Cytokines and the immune response, Biotherapy, 8, 243-249 (1996)

[4] Goff JP, Horst RL : Physiological changes at parturition and their relationship to metabolic disorders, J Dairy Sci, 80, 1260-1268 (1997)

[5] Kaneene JB, Miller R, Herdt TH, Gardiner JC : The association of serum nonesterified fatty acids and cholesterol, management and feeding practices with peripartum disease in dairy cows, Prev Vet Med, 31, 59-72 (1997)

[6] Saad AM, Concha C, Astrom G: Alterations in neutrophil phagocytosis and lymphocyte blastogenesis in dairy cows around parturition, Zentralbl Veterinarmed B, 36, 337-345 (1989)

[7] Holtenius K, Persson WK, Essen-Gustavsson B, Holtenius P, Hallen SC : Metabolic parameters and blood leukocyte profiles in cows from herds with high or low mastitis incidence, Vet $\mathrm{J}, 168,65-73$ (2004)

[8 ] Ohtsuka H, Kohiruimaki M, Hayashi T, Katsuta K, Matsuda K, Masui M, Abe R, Kawamura S : Relationship between leukocyte population and nutritive conditions in the dairy herd appeared frequently mastitis, J Vet Med Sci, 68, 113-118 (2006)

[9] 大塚浩通, 小松勝一, 小岩政照, 福田茂夫, 初谷 敦, 星 史雄, 吉野知男, 川村清市: 周産期疾病発生牛群に 対する免疫プロファイルテストの有用性, 日畜会報, 75 , 37-44 (2004)

[10] Riollet C, Rainard P, Poutrel B : Cell subpopulations and cytokine expression in cow milk in response to chronic Staphylococcus aureus infection, J Dairy Sci, 84, 1077-1084 (2001)

[11] Ohtsuka H, Watanabe C, Kohiruimaki M, Ando T, Watanabe D, Masui M, Hayashi T, Abe R, Koiwa M, Sato S, Kawamura S : Comparison of two different nutritive conditions against the changes in peripheral blood mononuclear cells of periparturient dairy cows, J Vet Med Sci, 68, in press (2006)

[12] 佐藤 繁, 河野充彦, 村山勇雄, 高橋孝幸, 鈴木利行 : 乳牛における分娩前の遊離脂肪酸值と分娩後の負の工ネ ルギーバランスの関係，日家畜臨会誌，28，1-6（2005）

[13] Shafer-Weaver KA, Pighetti GM, Sordillo LM : Diminished mammary gland lymphocyte functions parallel shifts in trafficking patterns during the postpartum period, Proc Soc Exp Biol Med, 212, 271-280 (1996)

[14] 大塚浩通, 小岩政照, 佐藤洋平, 山下政秀, 高田知哉, 伊東 登, 星 史雄, 吉野知男, 川村清市: 乳牛の乾乳 期における血清コレステロール值と分婏後の末梢白血球 との関係，日獣会誌，54，101-105（2001）

[15] Mosmann TR, Cherwinski H, Bond MW, Giedlin MA, Coffman RL : Two types of murine helper $\mathrm{T}$ cell clone. I. Definition according to profiles of lymphokine activities and secreted proteins, J Immunol, 136, 2348-2357 (1986)

[16] Allen JE, Maizels RM : Th1-Th2 : reliable paradigm or dangerous dogma?, Immunol Today, 18, 387-192 
(1997)

[17] Estes DM, Hirano A, Heussler VT, Dobbelaere DA, Brown WC : Expression and biological activities of bovine interleukin 4 : effects of recombinant bovine interleukin 4 on $\mathrm{T}$ cell proliferation and $\mathrm{B}$ cell differentiation and proliferation in vitro, Cell Immunol, 163, 268-279 (1995)

[18] Kubo M, Ransom J, Webb D, Hashimoto Y, Tada T, Nakayama $T$ : T-cell subset-specific expression of the IL-4 gene is regulated by a silencer element and STAT6, EMBO J, 16, 4007-4020 (1997)

[19] Marshall GD Jr, Agarwal SK, Lloyd C, Cohen L, Henninger EM, Morris GJ : Cytokine dysregulation associated with exam stress in healthy medical students, Brain Behav Immun, 12, 297-307 (1998)

[20] Suzuki K, Yamada M, Kurakake S, Okamura N, Yamaya K, Liu Q, Kudoh S, Kowatari K, Nakaji S, Sugawara K : Circulating cytokines and hormones with immunosuppressive but neutrophil-priming potentials rise after endurance exercise in humans, Eur J Appl Physiol, 81, 281-287 (2000)

[21] Shafer-Weaver KA, Corl CM, Sordillo LM. Shifts in bovine $\mathrm{CD}^{+}$subpopulations increase $\mathrm{T}$-helper-2 compared with T-helper-1 effector cells during the postpartum period, J Dairy Sci, 82, 1696-706 (1999)

[22] Robinson E, Segal R, Struminger L, Faraggi D, El'adYarum R, Mekori T : Lymphocyte subpopulations in patients with multiple primary tumors, Cancer, 85 , 2073-2076 (1999)

[23] Kimura K, Goff JP, Kehrli ME Jr, Harp JA : Phenotype analysis of peripheral blood mononuclear cells in periparturient dairy cows, J Dairy Sci, $82,315-319$ (1999)

[24] Van Kampen C, Mallard BA : Effects of peripartum stress and health on circulating bovine lymphocyte subsets, Vet Immunol Immunopathol, 59, 79-91 (1997)

Utility of Immunity Profiling of Dairy Herds During Peripaturient Periods Chika WATANABE* ${ }^{*}$, Hiromichi OHTSUKA ${ }^{\dagger}$, Masayuki KOHIRUIMAKI, Mayumi TOKITA, Sakiko TERASAWA, Takaaki ANDO, Daisaku WATANABE and Shigeru SATO

* Veterinary Internal Medicine, School of Veterinary Medicine, Kitazato University, 35-1 Higashi niju-san-ban-cho, Towada, 034-8628

\section{SUMMARY}

To clarify the utility of immunity profiling of dairy herds, we analyzed peripheral mononuclear cells and performed blood metabolic profiling of A, B and C dairy herds. The occurrence of peripaturient disease in Herd $A$ and $B$ was higher than it was in Herd C. In blood biochemical analysis, high non-esterified fatty acid (NEFA) was found in Herd A before calving. In herd B, levels of total cholesterol and glucose were higher compared with the levels in Herds A and C. In immunological analysis, the rates of $\mathrm{CD} 4^{+} / \mathrm{CD}^{+}$and $\mathrm{IFN}-\gamma / \mathrm{IL}^{-} 4$ in Herd A was between one and four months lower compared with the rates in Herds B and C. These findings suggested that there is suppression of the cellular immunological function after calving in A dairy herd with insufficient nutriment feeding content during the dry period.

- Key words : Dry period, immunological profile, nutrition, peripaturient disease.

$\dagger$ Correspondence to : Hiromichi OHTSUKA (School of Veterinary Medicine, Kitazato University)

35-1 Higashi niju-san-ban-cho, Towada, 034-8628, Japan

TEL 0176-23-4371FAX0176-23-8703 E-mail : otsuka@vmas.kitasato-u.ac.jp

J. Jpn. Vet. Med. Assoc., 60, $709 \sim 714$ (2007) 